
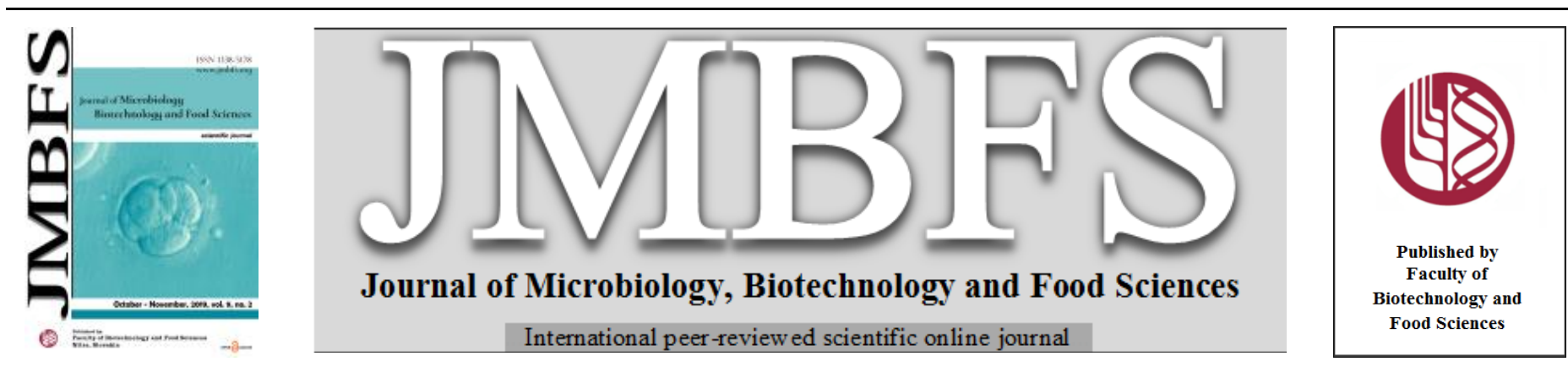

\title{
SIGNIFICANTLY LOWER CONTENT OF ANTINUTRITIONAL SOLUBLE OXALATE IN AMARANTH MUTANT LINES DEVELOPED BY RADIATION MUTAGENESIS
}

\author{
Andrea Hricová ${ }^{1}$, Jana Žiarovská ${ }^{2}$ Milan Suhaj ${ }^{3}$,Veronika Lancíková* ${ }^{* 1}$
}

\begin{abstract}
Address(es):
${ }^{1}$ Institute of Plant Genetics and Biotechnology, Plant Science and Biodiversity Center, Slovak Academy of Sciences, Department of Reproduction and Developmental Biology, Akademická 2, 95007 Nitra, Slovak Republic.

${ }^{2}$ Slovak University of Agriculture in Nitra, Faculty of Agribiology and Food Resources, Department of Genetics and Plant Breeding, Slovak University of Agriculture in Nitra, Trieda A. Hlinku 2, 94976 Nitra, Slovak Republic.

${ }^{3}$ Food Research Institute, Priemyselná 4, 82475 Bratislava, Slovak Republic.
\end{abstract}

*Corresponding author: veronika.lancikova@savba.sk

doi: $10.15414 / j m b f s .2020 .9 .4 .820-823$

\section{ARTICLE INFO}

Received 3. 4. 2019

Revised 15. 11. 2019

Accepted 19.11.2019

Published 3. 2. 2020

Regular article

OPEN $\partial_{\text {ACCESS }}$

\begin{abstract}
Soluble oxalate with potentially dietary injurious implications for human health were determined in amaranth (Amaranthus spp.) gamma-irradiation induced mutant lines by capillary isotachophoresis and compared to their non-irradiated reference samples 'Ficha' (Amaranthus cruentus L.) and interspecific hybrid 'K-433' (Amaranthus hypochondriacus $\times$ Amaranthus hybridus) during the cultivation period 2011-2014. The canonical discriminant analysis demonstrated significant differences among mutants and their reference counterparts during multiyear evaluation. Two-way ANOVA approach identified the mutant line D282 as variant with the significantly and long-term lowest soluble oxalate concentration in comparison to respective reference samples as well as other mutant lines. Decrease in a content of this antinutritional factor could be a possible effect of radiation-induced mutation event(s) in the D282 line genome. Therefore, this mutant line might be a good matrix in the further breeding programme of this naturally gluten-free pseudocereal.
\end{abstract}

Keywords: amaranth, soluble oxalate, nutrition, multivariate analysis

\section{INTRODUCTION}

Oxalic acid is a common and widespread constituent of plants, being found mostly at low levels in almost all plant families. It occurs in the form as the free acid, as soluble salts of potassium and sodium, and as insoluble salts of calcium, magnesium and iron (Noonan and Savage, 1999). The presence of soluble oxalate in foods may have important dietary implications (Trevaskis and Trenerry, 1997). A high dietary soluble oxalate intake influences mineral and trace element absorption in humans because it binds with $\mathrm{Ca}_{2}^{+}, \mathrm{Fe}^{+}$and $\mathrm{Mg}_{2}^{+}$ rendering these minerals unavailable. The insoluble calcium oxalate, however, is physiologically inert, its calcium is not ordinarily available and the oxalate remains unabsorbed (Shirley and Schmidt-Nielsen, 1967; Siener et al, 2006). The review published by Noonan and Savage (1999) highlighted the lack of data available on the oxalate content of common foods. Oxalic acid accumulates in plants especially during dry conditions (Bressani, 2003). In general, oxalate content is highest in the leaves, intermediate in the seeds and lowest in the stems (Cheeke and Bronson, 1980; Yadav and Sehgal, 2003). The mean daily intake of oxalate in English diets has been calculated to be 70-150 mg (Noonan and Savage, 1999).

Soluble (oxalic acid and soluble salts) and insoluble oxalate (predominantly the calcium salt) can be extracted from foods, using hot water to extract soluble oxalate, and dilute acids to extract total oxalate, which includes the insoluble oxalate fraction (Hodgkinson, 1997; Holloway, 1989). Oxalic acid is routinely determined by extraction and precipitation of calcium oxalate by AOAC methods (1980) or by titrimetric, spectrophotometric, high performance liquid chromatography (HPLC) or enzymatic methods (Trevaskis and Trenerry, 1997). Wet chemistry techniques to determine oxalate have been used by Zarembski and Hodgkinson (1962) and Hodgkinson (1997). High performance liquid chromatography (Holloway, 1989; Savage et al., 2000), enzymic methods (Chai and Liebman, 2005a), gas-liquid chromatography (GLC) (Ohkawa, 1985) or capillary electrophoresis (Chai and Liebman, 2005b; Trevaskis and Trenerry, 1997) can be used to quantify the extracted oxalate. Hönow and Hesse (2002) developed an HPLC-enzyme reactor method to measure oxalate in foods. In this method, water or acid-soluble oxalate were separated from matrix substances using an anion exchange column; an enzyme reactor was then used to convert the released oxalate to hydrogen peroxide, which was then measured amperometrically. For determination of oxalic acid in some Algae Watanabe $\boldsymbol{e}$ al. (1989) applied an oxalic acid sensor prepared with the combination of an oxalate oxidase membrane and an oxygen electrode.

Amaranthaceae, which are closely related to Chenopodiaceae, are widely distributed in the tropical and subtropical regions of the world. The consumption of some wild, marginalized or less known species continues, but there is still a tendency to replace them with cultivated species (Escudero et al., 1999). Having long been neglected by conventional agriculture, today these crops are receiving increasing recognition because of their potential role in ecosystem maintenance, in promoting diversity as well as in generating income and improving the malnutrition (Baldermann et al., 2016).

Amaranth (Amaranthus spp.) is an important vegetable and seed crop with high nutritional quality. However, presence of high levels of oxalate in some species of this plant poses a limitation on its usefulness as a human food source or livestock feed (Gupta and Wagle, 1988; Cheeke and Bronson, 1980; Pisarikova et al., 2006). It is inexpensive and a rich source of carotene, protein and ascorbic acid which serves as an alternative source of nutrition for vegetarians in developing countries. Besides nutritional value, it can grow successfully under varied soil and agro-climatic conditions (Shukla et al., 2003). Grain amaranth is a widely adaptable pseudocereal crop that has high protein and calcium concentrations and a lack of gluten. Pseudocereals like amaranth, with high numbers of species exhibiting a high degree of variability, may enhance biodiversity within cereal food supply and deliver essential ingredients as grain and vegetable crops suitable for variable climatic conditions and also for people with allergies.

Several studies performed by different authors showed that oxalate content is variable in different amaranths. Mean total oxalate concentration in the grain of 30 analyzed grain genotypes was $229 \mathrm{mg} / 100 \mathrm{~g}$, with values ranging between 178 and $278 \mathrm{mg} / 100 \mathrm{~g}$ (Gélinas and Seguin, 2007). In leaves of Amaranthus tricolor L. soluble oxalate content was 690 and total oxalate $1270 \mathrm{mg} / 100 \mathrm{~g} \mathrm{FW}$ (Gupta et al., 2005). The fresh leaves of Amaranthus tricolor $\mathrm{L}$. were analyzed for their content of oxalic acid. Oxalic acid content of the leaves ranged from 0.91 to 
$14.92 \mathrm{~g} / 100 \mathrm{~g}$. It was found that blanching and cooking resulted in a significant reduction in oxalic acid (Yadav and Sehgal, 2003). The foliage of 10 promising cultivars of vegetable amaranth from four cuttings was evaluated separately to gather information on different nutritional and antinutritional factors. The lowest oxalic acid content was in AV-45 $(0.06 \%)$ followed by AV-151 $(0.11 \%)$ (Gélinas and Seguin, 2007). Other investigation of soluble oxalate content in nuts of Amaranthus caudatus ranged from 55 to $107 \mathrm{mg} / 100 \mathrm{~g}$, with a tota oxalate ranging from 228 to $236 \mathrm{mg} / 100 \mathrm{~g}$ (Siener $\boldsymbol{e t}$ al., 2006). The oxalate concentration for the Amaranthus retroflexus species was found within the range of 2.66 to $5.36 \%$ (Siener et al., 2006; Escudero et al., 1999). On average the total oxalate content in a vegetable amaranth Amaranthus gangeticus was 91 g. $\mathrm{kg}^{-1}$ on a dry weight basis (Vityakon and Standal, 1989). The distribution of oxalate within a plant is uneven. Reports show that the petiole (stalks) of amaranth (Siener et al., 2006) contains significantly lower levels of oxalate than the leaves.

Over the past years a multidisciplinary approach was initiated in cooperation with International Atomic Energy Agency in Vienna with aim to improve quality and quantity of amaranth production through radiation mutagenesis and related biotechnology approaches (Gajdošová et al., 2007). As result, a collection of mutant lines was established and compared to the reference amaranths on the base of some biochemical characteristics and nutritional traits (Hricová et al. 2011; Kečkešová et al., 2012, 2013).

Herein, we present comparative study of soluble oxalate content in selected radiation obtained amaranth mutant lines and their reference non-irradiated controls (Amaranthus cruentus 'Ficha' and Amaranthus hypochondriacus $\times A$ hybridus 'K-433'). Comparative estimation looking for mutants with minimal content of antinutritional soluble oxalic acid was performed by analysis of variance and multivariate statistical approach.

\section{MATERIAL AND METHODS}

\section{Plant material and experimental design}

Two grain amaranth accessions were used for the gamma irradiation treatment genotype 'Ficha' (Amaranthus cruentus) and interspecific hybrid 'K-433' (A hypochondriacus $\times$ A. hybridus), both medium early cultivars with weight of thousand seeds (WTS) $0.85 \mathrm{~g}$ and $0.73 \mathrm{~g}$, respectively. Both seed samples were obtained from the collection of Gene Bank of the Research Institute of Plant Production Praha-Ruzyně, Czech Republic. Seeds were treated by a dose of 175 Gy in the Joint FAO/IAEA Programme Agency's laboratories in Seibersdorf, Austria (Gajdošová et al., 2007).

Twenty generations of selected mutant lines with their untreated counterparts ('Ficha' as control A and hybrid 'K-433' as control B) were established in the las two decades. Reference amaranth A was compared with appropriate irradiationderived mutant lines $\mathrm{C} 15, \mathrm{C} 26, \mathrm{C} 27, \mathrm{C} 82$ and $\mathrm{C} 236$ and reference $\mathrm{B}$ with derived lines D54, D279 and D282 on soluble oxalate content in ground seed samples harvested during the period 2011-2014 from Nitra region. The region is characterized as a warmer and dry area located on the south-western Slovakia (290 $\mathrm{m}$ above sea level) with mean annual precipitation $600 \mathrm{~mm}$ and mean annual temperature $9.5^{\circ} \mathrm{C}$.

\section{Extraction of soluble oxalate}

In order to determine the oxalic acid content by capillary isotachophoresis (CITP) a reported procedure of oxalate isolation by the simple water extraction method was used (Hönow and Hesse, 2002). For the determination a portion of $5 \mathrm{~g}$ of the homogenized samples were suspended with $20 \mathrm{ml}$ distilled water and subsequently shaken for $60 \mathrm{~min}$ at room temperature $\left(21^{\circ} \mathrm{C}\right)$ using a laboratory shaker (Innova 2000, New Brunswick Scientific, Edison, New Jersey, USA) at $3.3 \mathrm{~Hz}$ and subsequently the solid phase was removed by filtration on folded paper filter 604 1⁄2 (Schlieser and Schûell, Dassel, Germany).

\section{Capillary isotachophoretic determination}

Capillary isotachophoretic separations was performed using an electrophoretic analyser EA 202M (Villa Labeco, Spišská Nová Ves, Slovakia) with ITP Pro 32 (v. 1.0.5) software package for data processing. The method was developed and validated by Meissner et al. (1998) and Sádecká et al. (2008), respectively. Leading electrolyte: $5 \mathrm{mM} \mathrm{HCl}$ including $0.1 \%$ MHEC (methylhydroxyethylcellulose) adjusted with $\beta$-alanine to $\mathrm{pH} 3.5$; terminating electrolyte: $5 \mathrm{mM}$ citric acid; sample injection $30 \mu \mathrm{l}$, driving current in pre-separation capillary $200 \mu \mathrm{A}$, current in analytical capillary $20 \mu \mathrm{A}$; conductometric detection. The pre-separation capillary $(80 \mathrm{~mm} \times 0.8 \mathrm{~mm}$ i. d.) and analytical capillary (160 $\mathrm{mm} \times 0.3 \mathrm{~mm}$ i. d.) were made of fluorinated ethylene-propylene copolymer. Al analyses were performed in duplicate. Calibration curve for the sodium oxalate was performed in the range of concentrations from 0.5 to $10 \mathrm{mg} \cdot \mathrm{l}^{-1}$ with linear regression $\left(\mathrm{R}^{2}=0.996\right)$. From the calibration data limit of detection $\left(0.29 \mathrm{mg} \cdot \mathrm{l}^{-1}\right)$ and limit of quantification $\left(0.47 \mathrm{mg} . \mathrm{l}^{-1}\right)$ were determined by ISO $11843-2$ method using the QC Expert v.2.5 Trilobyte software statistical package.

\section{Statistical analysis}

The obtained data were subjected to two-way ANOVA to determine the differences between control variants and mutant lines across 4-year cultivation period. Statistical analysis was carried out by using Statistica 10 (StatSoft, Inc. 2011) software

In order to find possible tendencies in the samples and the discriminant power of the variables the canonical discriminant analysis was used. The presentation and visualisation of the results was done by Unistat v. 5.6 (Unistat, London, United Kingdom).

\section{RESULTS AND DISCUSSION}

This study examined the antinutritional soluble oxalic acid of five amaranth mutant lines of A. cruentus L. (C15, C26, C27, C82 and C236) and three mutants of hybrid A. hypochondriacus $\times$ A. hybridus (D54, D279 and D282) derived by radiation mutagenesis of genotype 'Ficha' (A. cruentus) and interspecific hybrid 'K-433' (A. hypochondriacus $\times$ A. hybridus). Comparative study on soluble oxalate content in ground seeds was performed on plant material grown during the period $2011-2014$ in Nitra region.

To gain deep insight into the differences among amaranth samples we applied a multivariate analysis on oxalic acid concentration data. The data were subdivided according to the observation years $2011-2014$ as comparative variables. The canonical discriminant analysis confirmed differences among compared amaranth reference and mutant samples as it is visible on the plot of canonical functions (Figure 1). First discriminant function was able to explain up to $94 \%$ of total variance concerning mainly the soluble oxalate variation in 2012 and 2013 years, which were the most discriminating time factors for distinguishing the compared groups of amaranths. The significance of shown differences on plot of discriminant functions is indicated by transposition of group samples as it was previously demonstrated by factor analysis. Moreover, significant differences demonstrated by canonical discrimination were confirmed by classification procedure which resulted in $100 \%$ correctly categorised all amaranth samples into their relevant groups

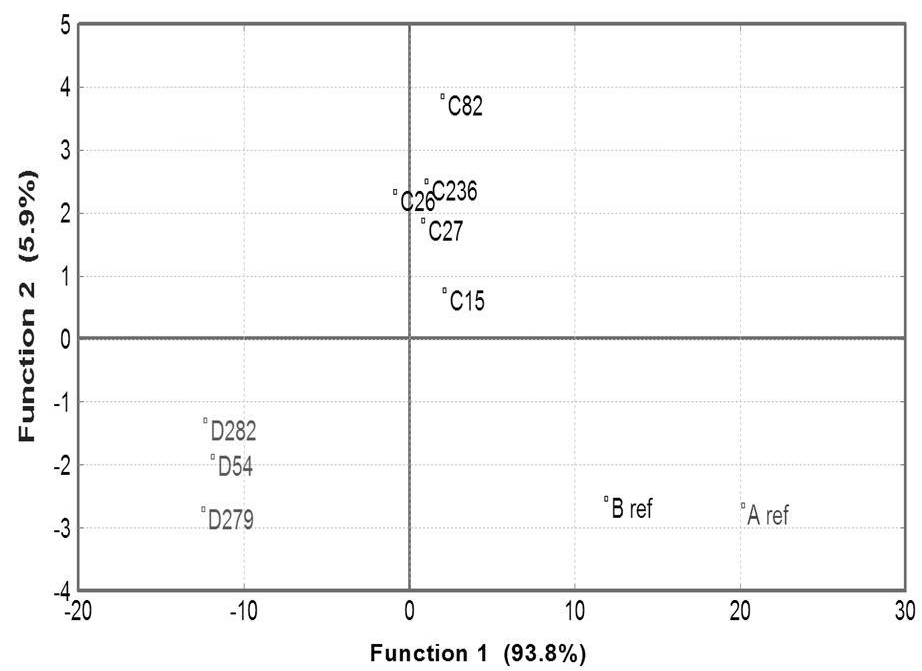

Figure 1 Differentiation of amaranth mutant lines from their reference samples by canonical discriminant analysis

Multiyear comparison of soluble oxalic acid content in all examined amaranth samples is shown in Table 1a. The content of this undesirable antinutritional factor ranged in tested amaranth seeds from 2.2 to $14.04 \mathrm{mg} \cdot \mathrm{kg}^{-1}$. Llelaboye and Pikuda (2009) determined several antinutritional factors such as tannins, saponins and oxalic acid in seeds of three less known crops - Jatropha cucas Trichosanthes cucumerina and Citrullus vulgaris. Among the seeds rich in oxalic acid, greatly affecting the mineral content, were the Citrullus vulgaris seeds $(40.65 \mathrm{mg} / 100 \mathrm{~g})$. The obtained values of oxalic acid in our study was found in lower levels in comparison to these data as well as some results reviewed for amaranth (Siener et al., 2006).

During the period of observation the biggest variability in oxalate content was found within C82 mutant line. In the case of comparison according to year of production the largest oxalate content was found in the year of 2012 and 2013 Considering the nutritional aspect the minimal content of oxalate $\left(2.2 \mathrm{mg} \cdot \mathrm{kg}^{-1}\right)$ was found in seeds of mutant line D282 in the 2011 year.

The data on soluble oxalate in amaranth seeds collected during the 4-year period of observation were subjected to analysis of variance by two-factor ANOVA (Table 1b). Statistical differences in soluble oxalic acid amount were determined between amaranth reference and mutant samples $(\mathrm{p}=0.000)$ and growing season $(\mathrm{p}=0.000)$. Two-way ANOVA statistical approach revealed high significant 
differences between reference amaranths and respective mutant lines $(\mathrm{p}<0.05, \mathrm{p}$ $<0.01$ ). Hybrid mutant lines (D54 - D282) showed highly significantly lower oxalate content in comparison to both non-irradiated control samples and to all $A$. cruentus lines $(\mathrm{C} 15-\mathrm{C} 236)$. Most interesting results were observed in the mutant line D282 that was identified as variant with the significantly and long- term lowest soluble oxalate concentration in comparison to respective reference samples as well as other mutant lines. This beneficial long-term suppression of oxalic acid in the D282 seeds could be a consequence of gamma-ray mutagenesis.

Table 1 Soluble oxalic acid content in seeds of eight amaranth mutant lines and two non-irradiated control samples harvested during the 2011-2014 period in Nitra region a)

\begin{tabular}{lllllllll}
\multirow{2}{*}{$\begin{array}{l}\text { Amaranth } \\
\text { variants }\end{array}$} & \multicolumn{8}{l}{ Soluble oxalic acid [mg.kg ${ }^{-1}$ ] } \\
\cline { 2 - 9 } & 2011 & & 2012 & & 2013 & & 2014 & \\
\cline { 2 - 9 } & $\mathbf{x}_{\text {mean }}$ & $\mathbf{S}_{\mathbf{x}}$ & $\mathbf{x}_{\text {mean }}$ & $\mathbf{S}_{\mathbf{x}}$ & $\mathbf{x}_{\text {mean }}$ & $\mathbf{S}_{\mathbf{x}}$ & $\mathbf{x}_{\text {mean }}$ & $\mathbf{S}_{\mathbf{x}}$ \\
\hline A control & 10.45 & 0.05 & 10.34 & 0.31 & 14.04 & 0.29 & 8.47 & 0.18 \\
C15 & 4.77 & 0.22 & 8.58 & 0.13 & 9.38 & 0.32 & 6.94 & 0.10 \\
C26 & 4.13 & 0.05 & 10.03 & 0.21 & 9.26 & 0.66 & 7.4 & 0.27 \\
C27 & 6.02 & 0.25 & 7.39 & 0.03 & 9.63 & 0.30 & 5.22 & 0.37 \\
C82 & 4.75 & 0.13 & 11.97 & 0.06 & 11.30 & 0.55 & 7.67 & 0.30 \\
C236 & 5.36 & 0.24 & 8.18 & 0.06 & 6.17 & 3.3 & 9.14 & 0.06 \\
B control & 10.05 & 0.5 & 7.89 & 0.03 & 12.16 & 0.59 & 6.53 & 0.34 \\
D54 & 4.42 & 0.18 & 5.59 & 0.02 & 4.16 & 0.13 & 5.23 & 0.90 \\
D279 & 3.64 & 0.24 & 6.71 & 0.03 & 5.21 & 0.27 & 3.50 & 0.23 \\
D282 & 2.20 & 0.25 & 2.42 & 0.01 & 3.47 & 0.13 & 2.88 & 0.07 \\
\hline
\end{tabular}

b)

\begin{tabular}{llll}
$\begin{array}{l}\text { Amaranth } \\
\text { variants }\end{array}$ & $\begin{array}{l}\text { Means } \\
{\left[\mathbf{m g . k g}^{-1}\right]}\end{array}$ & $\boldsymbol{\alpha}=\mathbf{0 . 0 5}$ & $\boldsymbol{\alpha}=\mathbf{0 . 0 1}$ \\
\hline D282 & 2.74 & $\mathrm{a}$ & $\mathrm{a}$ \\
D279 & 4.77 & $\mathrm{~b}$ & $\mathrm{a}, \mathrm{b}$ \\
D54 & 4.85 & $\mathrm{~b}$ & $\mathrm{~b}$ \\
$\mathrm{C} 27$ & 7.07 & $\mathrm{c}$ & $\mathrm{c}$ \\
$\mathrm{C} 236$ & 7.22 & $\mathrm{c}$ & $\mathrm{c}, \mathrm{d}$ \\
$\mathrm{C} 15$ & 7.42 & $\mathrm{c}, \mathrm{d}$ & $\mathrm{c}, \mathrm{d}$ \\
$\mathrm{C} 26$ & 7.71 & $\mathrm{c}, \mathrm{d}, \mathrm{e}$ & $\mathrm{c}, \mathrm{d}$ \\
C82 & 8.93 & $\mathrm{~d}, \mathrm{e}$ & $\mathrm{d}, \mathrm{e}$ \\
B control & 9.16 & $\mathrm{e}$ & $\mathrm{d}, \mathrm{e}$ \\
A control & 10.83 & $\mathrm{f}$ & $\mathrm{e}$ \\
\hline
\end{tabular}

(a-f) Different letters represent significant differences by LSD test at respective probability level

The response to gamma-ray irradiation treatment and radiation genetic effect can be observed and different quantitative and qualitative characteristics and traits can be positively modified what leads to improvement of existing or developmen to the new varieties. Mutation-based breeding involves the development of new crop varieties by generating and utilizing genetic variability through chemical and physical mutagenesis (Gomez Pando et al., 2013). Currently, over 3200 registered mutant varieties covering 232 different crops have been developed using induced mutagenesis (Mehlo et al., 2013; IAEA, 2015; reviewed in Oladosu et al., 2016). Many of these varieties have significantly contributed to an improvement in the socio-economic conditions of farmers. Thus, mutation breeding has big potential for agriculture and is important approach of modern plant breeding.

\section{CONCLUSION}

Analysis of gamma irradiation-derived mutants revealed differences in the content of one of the antinutritional factors - soluble oxalic acid. The hybrid mutant line D282 was found as variant with the significantly lowest soluble oxalate concentration in seeds in comparison to its reference counterpart as well as other mutant lines of the current report. This mutant line was able to hold this anti-nutritional quality aspect during four years of cultivation. Decrease in a content of the antinutritional substance, that generally limit the nutrient availability to the human body, could be a possible effect of radiation-induced mutation event(s) in the D282 line genome. Thus, a further task would involve unravelling the genetic basis of the reported (mutant) trait.

Acknowledgements: This work was supported by COST CA18101: Sourdough biotechnology network towards novel, healthier and sustainable food and bioprocesses (SOURDomics) and European Community project no. 26220220180: Building Research Centre "Agrobiotech".

\section{REFERENCES}

AOAC (Association of Official Analytical Chemists) 1980. Official Methods of Analysis, Thirteenth ed., Washington, DC

BALDERMANN, S., BLAGOJEVIĆ, L., FEREDE, K., KLOPSH, R., NEUGART, S., NEUMANN, A., HGWENE, B., NORKWEIT, J., SCHRÖTER, D., SCHRÖTER, A., SCHWEIGERT, F.J., WIESNER, M., SCHREINER, M Are neglected plants the food for the future? Critical Reviews in Plant Sciences, 35, 106-119, http://doi.org/10.1080/07352689.2016.1201399

BRESSANI, R. 2003. Amaranth. Encyclopedia of Food Sciences and Nutrition, Caballero, B. (Ed.), Academic Press, Oxford, 166-173. http://dx.doi.org/10.1016/B0-12-227055-X/00036-5

CHAI, W., LIEBMAN, M. 2005a. Effect of different cooking methods on vegetable oxalate content. Journal of Agricultural and Food Chemistry, 53, 3027-3030. https://doi.org/10.1021/jf048128d

CHAI, W., LIEBMAN, M. 2005b. Oxalate content of legumes, nuts, and grainbased flours. Journal of Food Composition and Analysis, 18, 723-729. https://doi.org/10.1016/j.jfca.2004.07.001

CHEEKE, P.R., BRONSON, J. 1980. Feeding trials with Amaranthus grain, forage and leaf protein concentrations. Proceedings of $2^{\text {nd }}$ Amaranth Conference, Rodale Press, Emmaus, 5-11.

ESCUDERO, N.L., ALBARRACÍN, G., FERNÁNDEZ, S., DE ARELLANO, L.M., MUCCIARELLI, S. 1999. Nutrient and anti-nutrient composition of
Amaranthus muricatus. Plant Foods for Human Nutrition, 54, 327-336. https://doi.org/10.1023/A:1008149721435

GAJDOŠOVÁ, A., LIBIAKOVÁ, G., FEJÉR, J. 2007. Improvement of selected Amaranthus cultivars by means of mutation induction and biotechnological approaches. Breeding of Neglected and Under-Utilized Crops, Spices and Herbs. Ochatt, S., Jain, S.M. (Eds.) Science Publishers, Enfield, New Hampshire, 151169. https://doi.org/10.1201/9781482280548

GÉLINAS, B., SEGUIN, P. 2007. Oxalate in grain amaranth. Journal of Agricultural and Food Chemistry, 55, 4789-4794. https://doi.org/10.1021/jf070384d

GOMEZ PANDO, L. R., EGUILUZ de la BARRA, A. 2013. Developing genetic variability of quinoa (Chenopodium quinoa Willd.) with gamma radiation for use in breeding programs. American Journal of Plant Science, 4, 349-355. http://dx.doi.org/10.4236/ajps.2013.42046

GUPTA, K., WAGLE, D.S. 1988. Nutritional and anti-nutritional factors of green leafy vegetables. Journal of Agriculture and Food Chemistry, 36, 472-474 https://doi.org/10.1021/jf00081a016

GUPTA, S., LAKSHMI, A.J., MANJUNATH, M.N., PRAKASH, J. 2005 Analysis of nutrient and antinutrient content of underutilized green leafy vegetables. Food Science and Technology, 38, 339-345. https://doi.org/10.1016/j.1wt.2004.06.012

HODGKINSON, A. 1997. Oxalate content of foods and nutrition. Oxalic Acid in Biology and Medicine. Academic Press, Hodgkinson, A. (Ed.), London, 1977, pp 193-212.

HOLlOWAY, W.D., ARGALL, M.E., JEALOUS, W.T., LEE, J.A., BRADBURY, J.H. 1989. Organic acids and calcium oxalate in tropical roo crops. Journal of Agricultural and Food Chemistry, 37, 337-341. https://doi.org/10.1021/jf00086a014

HÖNOW, R., HESSE, A. 2002. Comparison of extraction methods for the determination of soluble and total oxalate in foods by HPLC-enzyme-reactor. Food Chemistry, 78, 511-521. https://doi.org/10.1016/s0308-8146(02)00212-1 HRICOVÁ, A., FEJÉR, J., LIBIAKOVÁ, G., SZABOVÁ, M., GAŽO, J., GAJDOŠOVÁ, A. 2016. Characterization of phenotypic and nutritional properties of valuable Amaranthus cruentus L. mutants. Turkish Journal of Agriculture and Forestry, 40, 761-771. https://doi.org/10.3906/tar-1511-31 HRICOVÁ, A., KEČKEŠOVÁ, M., GÁlOVÁ, Z., LIBIAKOVÁ, G. GAJDOŠOVÁ, A. 2011. Investigation of protein profile changes in amaranth seeds after radiation mutagenesis. Chemické Listy, 105, 542-545.

IAEA. IAEA mutant database. Vienna: International Atomic Energy Agency; c2015 [accessed July 2015]. Available from: http://mvd.iaea.org/

KEČKEŠOVÁ, M., GÁLOVÁ, Z., HRICOVÁ, A. 2012. Changes of protein profiles in amaranth mutant lines. Journal of Microbiology, Biotechnology and Food Sciences, 1, 1129-1135.

KEČKEŠOVÁ, M., PALENČÁROVÁ, E., GÁlOVÁ, Z., GAŽO, J., HRICOVÁ, A. 2013. Nutritional quality of grain amaranths (Amaranthus L.) compared to putative mutant lines. Journal of Microbiology, Biotechnology and Food Sciences, 2 (Special Issue on BQRMF), 1716-1724.

LLELABOYE, N.O.A., PIKUDA, O.O. 2009. Determination of minerals and anti-nutritional factors of some lesser-known crop seeds. Pakistan Journal of Nutrition, 8, 1652-1656. 10.3923/pjn.2009.1652.1656

MEHLO, L.., MBAMBO, Z., BADO, S., LIN, J., MOAGI, S. M., BUTHELEZI, S., STOYCHEV, S., CHIKWAMBA, R. 2013. Induced protein polymorphisms and antinutritional quality of gamma irradiation mutants of sorghum. Mutation Research, 749, 66-72. https://doi.org.10.1016/j.mrfmmm.2013.05.002

MEISSNER, T., EISENBEISS, F., JASTORFF, B. 1998. Determination of anionic trace impurities in glycerol by capillary isotachophoresis with enlarged 
sample load. Journal of Chromatography A, 810, 201-208. https://doi.org/10.1016/s0021-9673(98)00236-2

NOONAN, S.N., SAVAGE, G. 1999. Oxalate content of foods and its effect on humans. Asia Pacific Journal of Clinical Nutrition, 8, 64-74. https://doi.org/10.1046/j.1440-6047.1999.00038.x

OHKAWA, H. 1985. Gas chromatographic determination of oxalic acid in foods Journal of the Association of Official Analytical Chemists, 68, 108-111.

OLADOSU, Y., RAFII, M. Y., ABDULLAH, N., HUSSIN, G., RAMLI, A., RAHIM, H. A., MIAH, G., USMAN, M. 2016. Principle and application of plant mutagenesis in crop improvement: a review. Biotechnology \& Biotechnological Equipment, 30, 1-16. http://dx.doi.org/10.1080/13102818.2015.1087333

PISARIKOVA, B., ZRALY, Z., KRACMAR, S., TRCKOVA, M., HERZIG, I. 2006. The use of amaranth (genus Amaranthus L.) in the diets for broiler chickens. Veterinarni Medicina, 51, 399-407. https://doi.org/10.17221/5560vetmed

SÁDECKÁ, J., MÁJEK, P., TÓTHOVÁ, J. 2008. CE profiling of organic acids in distilled alcohol beverages using pattern recognition analysis. Chromatographia, 67, S69-S74. https://doi.org/10.1365/s10337-007-0513-2

SAVAGE, G.P., VANHANEN, L., MASON, S.M., ROSS, A.B. 2000. Effect of cooking on the soluble and insoluble oxalate content of some New Zealand foods. Journal of Food Composition and Analysis, 13, 201-206. https://doi.org/10.1006/jfca.2000.0879

SHIRLEY, E.K., SCHMIDT-NIELSEN, K. 1967. Oxalate metabolism in the pack rat, sand rat, hamster and white rat. Journal of Nutrition, 91, 496-502. https://doi.org/10.1093/jn/91.4.496

SHUKLA, S., PANDEY, V., PCHAURI G., DIXIT, B.S., BANETJI, R., SINGH, S.P. 2003. Nutritional contents of different foliage cuttings of vegetable amaranth. Plant Foods for Human Nutrition, 58, 1-8. https://doi.org/10.1023/b:qual.0000040338.33755.b5

SIENER, R., HÖNOW, R., SEIDLER, A., VOSS, S., HESSE, A. 2006. Oxalate contents of species pf the Polygonaceae, Amaranthaceae and Chenopodiaceae $\begin{array}{llll}\text { families. Food } & \text { Chemistry, 220-224 }\end{array}$ https://doi.org/10.1016/j.foodchem.2005.05.059

SNEDECOR, G.W., COCHRAN, W.G. 2006. Statistical Methods. $6^{\text {th }}$ Ed. Ame Iowa State University Press, Iowa.

TREVASKIS, M., TRENERRY, V.C. 1997. The determination of oxalic acid in vegetables by capillary electrophoresis. AGAL Public Interest Program, Australian Government Analytical Laboratories, AGAL Publication, Canberra. VITYAKON, P., STANDAL, B.R. 1989. Oxalate in vegetable amaranth (Amaranthus gangeticus) forms, contents, and their possible implications for human health. Journal of the Science of Food and Agriculture, 48, 469-474 https://doi.org/10.1002/jsfa.2740480409

WATANABE, E., HASHIMOTO, T., KONNO, T., TOYAMA, K. 1989. Determination of oxalic acid in Algae with an enzyme sensor. Nippon Suisan Gakkaishi, 55, 911-915. https://doi.org/10.2331/suisan.55.911

YADAV, S.K., SEHGAL, S. 2003. Effect of domestic processing and cooking on selected anti-nutrient contents of some green leafy vegetables. Plant Foods for Human Nutrition, 58, 1-11. https://doi.org/10.1023/b:qual.0000040359.40043.4f ZAREMBSKI, P.M., HODGKINSON, A. 1962. The oxalic acid content of English diets. British Journal of Nutrition, 16, 627-634. https://doi.org/10.1079/bjn19620061 